\title{
Distribution of the European water vole Arvicola amphibius (Linnaeus, 1758) in Mazowsze and southern Podlasie
}

\author{
Grzegorz LESIŃSKI ${ }^{1}$, Marek KowALSKI ${ }^{2}$, Przemysław STOLARZ ${ }^{3}$, \\ Jakub GRYZ ${ }^{4}$, Dagny KRAUZE-GRYZ ${ }^{5}$ and Jerzy ROMANOWSKI ${ }^{6}$ \\ ${ }^{1}$ Faculty of Animal Science, Warsaw University of Life Sciences - SGGW, Ciszewskiego 8, 02-787 Warsaw, Poland; \\ e-mail: glesinski@wp.pl (corresponding author) \\ ${ }^{2}$ Wildlife Society “Stork”, Jagietly 11,08-110 Siedlce, Poland; e-mail: marek@bocian.org.pl \\ ${ }^{3}$ Center for Human Ecology, Kościuszki 24,05-075 Warsaw-Wesoła, Poland; e-mail: przem.stolarz@gmail.com \\ ${ }^{4}$ Forest Research Institute, Sękocin Stary, Braci Leśnej 3, 05-090 Raszyn, Poland; e-mail: J.Gryz@ibles.waw.pl \\ ${ }^{5}$ Faculty of Forestry, Warsaw University of Life Sciences - SGGW, Nowoursynowska 159, \\ 02-776 Warsaw, Poland; e-mail: dagny.krauze@wl.sggw.pl \\ ${ }^{6}$ Faculty of Biology and Environmental Studies, Cardinal Stefan Wyszyński University, \\ Wóycickiego 1/3, 01-938 Warsaw, Poland; e-mail: j.romanowski@uksw.edu.pl
}

\begin{abstract}
The paper presents distribution of the European water vole Arvicola amphibius (Linnaeus, 1758) in Mazowsze and southern Podlasie in areas situated within a 120-kilometer radius from Warsaw. Data published so far and unpublished results from analyses of the diet of three common species of owls were set up. The rodent is rare in the study area, especially when compared with southern, western and far northern Poland. Its largest population lives in Kampinos Forest, from where many localities are known. In other parts of the study area it is present locally. Only 14 localities were known outside Kampinos Forest in the years 2000-2017. It is even absent from large areas rich in various water bodies like e.g. Mazowiecki and Chojnowski Landscape Parks or Bolimowska Forest. Rarity of the European water vole was confirmed by 235 large samples of owls' food (at least 100 of vertebrate prey in each) equally distributed across Mazowsze and southern Podlasie, in which this species was not found.
\end{abstract}

Key words: Rodentia, Arvicollinae, distribution, Central Poland

\section{INTRODUCTION}

Taxonomic status of Polish water voles Arvicola sp. is still not clear. Some of subspecies of previously distinguished species - A. terrestris (Linnaeus, 1758) - in the last decades have been considered as separate species. It cannot be excluded that in Poland there are two species: European water vole A. amphibius (Linnaeus, 1758) and montane water vole A. scherman (Shaw, 1801). The range of the latter covers the area of south part of the country (the region of Carpathian Mountains) where the subspecies A. terrestris scherman was recorded (Cassola 2016). Populations of this species show different habitat preferences (ecotype) than $A$. amphibius from the central and north Poland (Cais 1974).

The range of the European water vole covers most of the area of Poland, especially lowlands. Many localities of this species known till the year 1980 mainly were found during analyses of the owls' pellets (Raczyński 1983). Least localities were noted in those days in central Poland, especially in Mazowsze. One could have assumed that the picture was a bit distorted due to relatively small number of analysed sites in this part of the country and could have expected that further studies would reveal other localities of this species. However, the number of localities of the European water vole in central Poland has not increased recently (Zub 2017). 
The aim of this study was to set up published and unpublished data on the distribution of the European water vole in Mazowsze and southern Podlasie and to estimate the status of its occurrence.

\section{STUDY AREA, MATERIAL AND METHODS}

Study area covered mainly Mazovian Lowland and fragment of southern Podlasie and was situated within a 120-kilometre radius from Warsaw. This is a lowland area cross-cut by large rivers: the Vistula, Bug, Narew, Pilica, Wieprz, Bzura, Wkra and Liwiec. Quite numerous oxbow lakes are present in the largest valleys. Larger wetlands are present in central and eastern part of the study area. Locally, especially in eastern, south-eastern and extremely western part, there are complexes of fishponds. Apart from published records, unpublished data collected in the years 1980-2017 from analyses of pellets of common owl species: the barn owl Tyto alba (Scopoli, 1769), long-eared owl Asio otus (Linnaeus, 1758) and tawny owl Strix aluco (Linnaeus, 1758) were also used in this study. Such material is a very good source of information on the distribution of small mammals including the European water vole. In regions, where the vole is common and numerous, it is often found in the diet of the barn owl (Wieluńska Upland - Lesiński 1991), long-eared owl (northern Podlasie - Lesiński et al. 2016b), or tawny owl (northern Podlasie - Lesiński et al. 2009, Gryz et al. 2011a).

The paper presents also data on sites, where the European water vole was not found in samples of owls' food containing at least 100 vertebrate prey items. There were 235 such samples (Appendix). This was done to delineate fragments of the study area, where the rodent is most probably absent.

\section{RESULTS}

Distribution of known localities of the European water vole in the study area (Table 1) was quite uneven. Till the end of the 20th century in the neighbourhood of Warsaw it was found only in Kampinos Forest. Larger groups of localities were noted in far northern part of the study area. One locality was known from southern Mazowsze (near Tomaszów Mazowiecki). In the years 2000-2017 the presence of the rodent was confirmed in Kampinos Forest, where it appeared rather common and numerous. It was also found in western Mazowsze (Głuchów, Popień, Drobin, Leszczyny Kolonia, Jeżewo), at the southern edge of Warsaw (Wilanów), in Kozienice Forest (in three squares of the Atlas of Polish Mammals), in southern Podlasie (Nowa Sucha, Kopcie, Suchożebry and surroundings of Siedlce).

Table 1. Localities of the European water vole noted in the study area (first records in particular sites from two study periods: 1957-1999 and 2000-2016 are presented).

In material from owl pellets: OP - without determination of species, Ao - Asio otus, Sa - Strix aluco, Ta - Tyto alba; number of individuals in parentheses, KNP - Kampinos National Park, APM - Atlas of Polish Mammals

\begin{tabular}{lclcc}
\hline Site & Square of APM & Date & Details of finding & Source of data \\
\hline Bogate & & Years 1957-1999 & \\
Miastkowo & $14 \mathrm{Gc}$ & 1957 & OP & Raczyński 1983 \\
Mława & $16 \mathrm{Fh}$ & 1957 & OP & Raczyński 1983 \\
Ostrołęka & $13 \mathrm{Fi}$ & 1957 & OP & Raczyński 1983 \\
Rzekuń & $16 \mathrm{Fg}$ & 1957 & OP & Raczyński 1983 \\
Poniatowo & $16 \mathrm{Fj}$ & 1957 & OP & Raczyński 1983 \\
Raciąż & $19 \mathrm{Fl}$ & 1965 & OP & Raczyński 1983 \\
Wielki Łęck & $13 \mathrm{Gg}$ & 1965 & OP & Raczyński 1983 \\
Nature reserve „Niebieskie & $12 \mathrm{Ff}$ & 1965 & OP & Raczyński 1983 \\
Źródła” & $13 \mathrm{Kd}$ & Jun 26, 1968 & Two individuals observed & Bartosz \& \\
& & & & Markowski 1972 \\
\hline
\end{tabular}


Continuation of the Table 1

\begin{tabular}{|c|c|c|c|c|}
\hline Site & Square of APM & Date & Details of finding & Source of data \\
\hline Łąki Strzeleckie (KNP) & $14 \mathrm{Hk}$ & 1970 & Caught in traps & Babińska 1972 \\
\hline Górzno & $12 \mathrm{Fd}$ & 1971 & OP & Raczyński 1983 \\
\hline Jamno (Okręt pond) & 12Il & 1972-1976 & $\mathrm{OP}$ & Raczyński 1983 \\
\hline Grabina (KNP) & 14Ia & Jun 7 and 11, 1981 & Ao (9) & Unpublished data \\
\hline Grabowy Grąd (KNP) & $14 \mathrm{Hi}$ & Jun 22, 1982 & Sa (5) & Lesiński et al. 2013 \\
\hline Ławy (KNP) & $14 \mathrm{Ib}$ & Jun 8, 1983 & Ao (1) & Unpublished data \\
\hline Młynisko (KNP) & $14 \mathrm{Hk}$ & May 25, 1983 & Sa (1) & Lesiński et al. 2013 \\
\hline $\begin{array}{l}\text { Kępa Kiełpińska near } \\
\text { Łomianki }\end{array}$ & $14 \mathrm{Hl}$ & 1983 & Ao (1) & $\begin{array}{c}\text { Romanowski 1988, } \\
\text { unpublished data }\end{array}$ \\
\hline Palmiry Łomna (KNP) & $14 \mathrm{Hk}$ & Jul 18, 1984 & Sa (1) & Lesiński et al. 2013 \\
\hline Gutocha near Jednorożec & $15 \mathrm{Fe}$ & Apr 1, 1985 & OP (1) & Unpublished data \\
\hline Stefanów & $16 \mathrm{Jh}$ & Jun 14,1990 & Ao (1) & Unpublished data \\
\hline Suchodół & 16Ic & Jul 15, 1990 & Sa (1) & Unpublished data \\
\hline Baranowo & $15 \mathrm{Fe}$ & Jun 26, 1991 & Та (1) & Unpublished data \\
\hline Bońkowo Kościelne & $13 \mathrm{~Gb}$ & Nov 6, 1993 & Та (1) & Unpublished data \\
\hline Niedzbórz & $13 \mathrm{GC}$ & Nov 6, 1993 & Sa (1) & Unpublished data \\
\hline Korfowe (KNP) & 14Ia & Jul 12, 1999 & Sa (2) & Lesiński et al. 2013 \\
\hline \multicolumn{5}{|c|}{ Years 2000-2017 } \\
\hline Kopcie near Grębków & 17Ia & 2000 & Та (1) & Urbanek 2004 \\
\hline Posada Demboskie (KNP) & $13 \mathrm{Hl}$ & Mar 31, 2000 & Sa (3) & Lesiński et al. 2013 \\
\hline Drobin & $12 \mathrm{Gl}$ & May 20, 2000 & Тa (1) & Unpublished data \\
\hline Suchożebry & $17 \mathrm{Ib}$ & Jul 14, 2000 & Та (1) & Unpublished data \\
\hline Głuchów & $13 \mathrm{Jg}$ & 2002 & Sa (2) & $\begin{array}{l}\text { Gryz et al. 2011b, } \\
\text { unpublished data }\end{array}$ \\
\hline $\begin{array}{l}\text { Division } 83 \text { of the Kampinos } \\
\text { Forest District (KNP) }\end{array}$ & 14Ia & Apr 2003 & Sa (1) & Lesiński et al. 2013 \\
\hline Warsaw Wilanów & $15 \operatorname{Ig}$ & Apr 19, 2004 & Sa (1) & $\begin{array}{l}\text { Gryz et al. 2008, } \\
\text { unpublished data }\end{array}$ \\
\hline Pionki & $15 \mathrm{Ki}$ & 2010 & Observations - Sławomir Wąsik & Zub 2017 \\
\hline Kociołki & $16 \mathrm{Kd}$ & 2010 & Observations - Sławomir Wąsik & Zub 2017 \\
\hline Policzna & $16 \mathrm{Kg}$ & 2010 & Observations - Sławomir Wąsik & Zub 2017 \\
\hline Kępa & 16 If & May 3, 2010 & $\begin{array}{l}\text { Remains of one ind. eaten by } \\
\text { predator - Agnieszka Parapura }\end{array}$ & Zub 2017 \\
\hline Popień & 12Ji & Apr 10, 2011 & Sa (1) & $\begin{array}{l}\text { Gryz et al. 2011b, } \\
\text { unpublished data }\end{array}$ \\
\hline Brzozówka (KNP) & $14 \mathrm{Hj}$ & Jul 20, 2011 & Ao (2) & Unpublished data \\
\hline Na Miny (KNP) & $14 \mathrm{Ib}$ & Oct 3, 2011 & Sa (2) & Lesiński et al. 2013 \\
\hline Kaliszki (KNP) & $14 \mathrm{Hk}$ & Nov 8, 2011 & Sa (1) & Lesiński et al. 2013 \\
\hline Cyganka (KNP) & $14 \mathrm{Ib}$ & Mar 12, 2012 & Sa (1) & Lesiński et al. 2013 \\
\hline Dąb Kobendzy (KNP) & $13 \mathrm{Hl}$ & Mar 16, 2012 & Sa (1) & Lesiński et al. 2013 \\
\hline Zaborów (KNP) & $14 \mathrm{Ib}$ & Mar 2012 & Ao (2) & $\begin{array}{l}\text { Lesiński et al. } \\
\text { 2016b }\end{array}$ \\
\hline Łazy Leśne (KNP) & 13Ic & Apr 11, 2012 & Sa (2) & Lesiński et al. 2013 \\
\hline Grabowy Grąd (KNP) & $14 \mathrm{Hi}$ & Apr 22, 2012 & Sa (5) & Lesiński et al. 2013 \\
\hline $\begin{array}{l}\text { Nature reserve Stawy } \\
\text { Siedleckie }\end{array}$ & 17Ie & Apr 28, 2012 & $\begin{array}{c}\text { Two observations and a burrow - } \\
\text { Martyna Paczuska }\end{array}$ & Zub 2017 \\
\hline Izabelin (KNP) & $14 \mathrm{Ib}$ & May 2, 2012 & Sa (1) & Lesiński et al. 2013 \\
\hline Stara Dąbrowa (KNP) & $14 \mathrm{Hj}$ & May 3, 2012 & Sa (1) & Lesiński et al. 2013 \\
\hline Ławy (KNP) & $14 \mathrm{Ib}$ & Jun 3, 2012 & Sa (2) & Lesiński et al. 2013 \\
\hline Roztoka (KNP) & 14Ia & Sep 20, 2012 & Sa (1) & Lesiński et al. 2013 \\
\hline Famułki Brochowskie (KNP) & 13Ic & May 2014 & Sa (2) & Unpublished data \\
\hline Lipków (KNP) & $14 \mathrm{Ib}$ & Jul 3, 2015 & Sa (1) & Unpublished data \\
\hline Nowa Sucha & 16 If & Mar 28, 2015 & Sa (1) - Przemysław Stolarz & Zub 2017 \\
\hline Leszczyny Kolonia & $12 \mathrm{Ji}$ & Apr 7, 2016 & $\begin{array}{c}\text { One individual observed - Jerzy } \\
\text { Borowski }\end{array}$ & Unpublished data \\
\hline Jeżewo near Zawidz & $12 \mathrm{Gh}$ & Jul 11, 2017 & Ao (1) & Unpublished data \\
\hline
\end{tabular}


From some areas we have data originating from long-term studies (Table 1, Appendix). In a village Bogate in northern Mazowsze, the rodent was recorded in 1950s but a large sample of owl pellets from the years 1991-2009 did not reveal its presence. Similarly, near Mława it was found in 1957 but was not recorded in the years 2015-2016 and on Kępa Kiełpińska, where the rodent was noted in 1983 but not in 1995-1996.

Analyses of communities of small mammals recorded in large samples of owls' food (Figure \& Appendix) revealed many regions, where the European water vole was probably absent. It was not present in larger parts of Płońsk and Ciechanów Uplands, Bolimowska Forest, Chojnowski and Mazowiecki Landscape Parks, Rembertów-Okuniew Forests and in Sterdyń Forests (between Nur and Sterdyń). In most of these sites, there are various water bodies and wetlands.

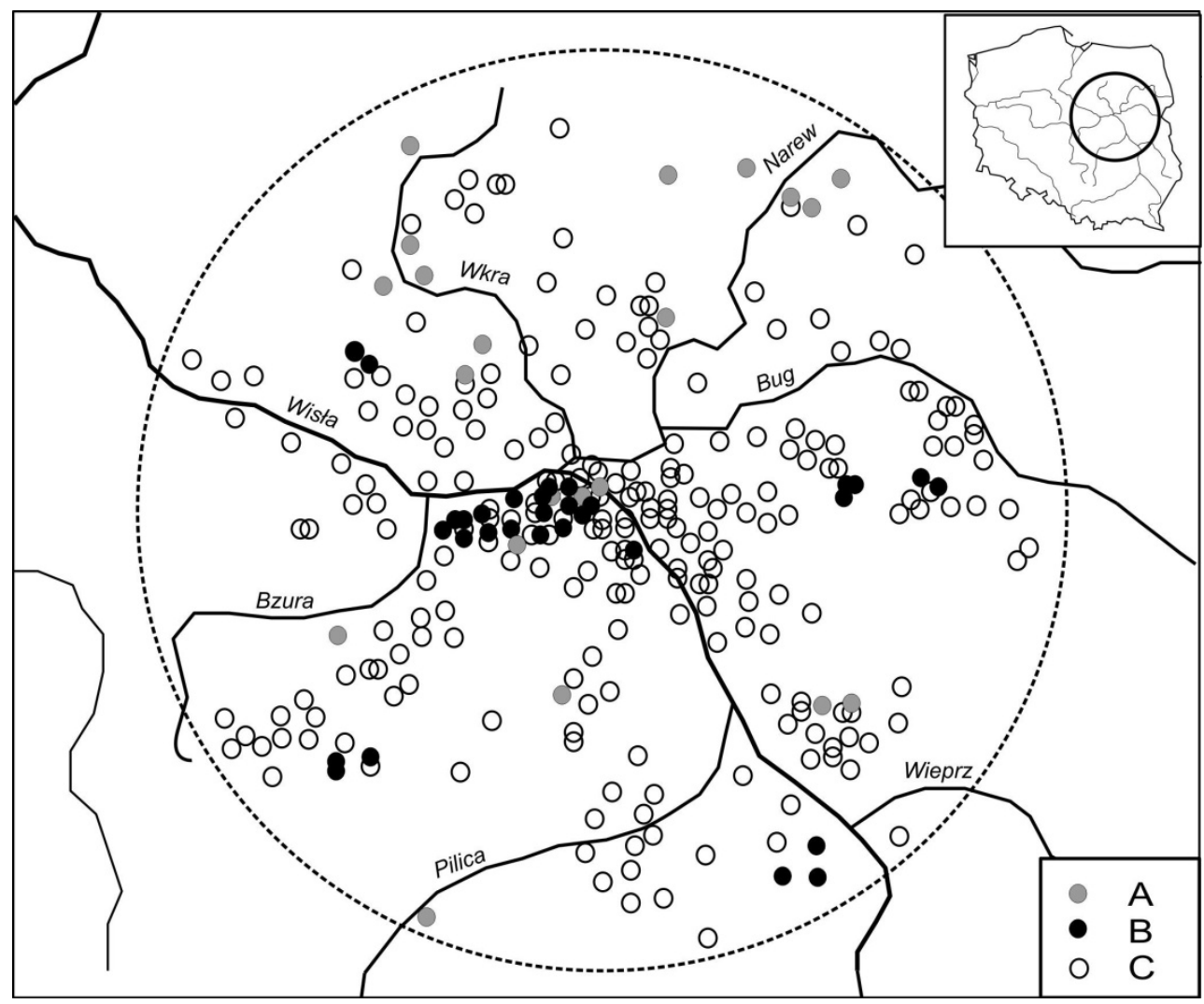

Figure. Distribution of localities of the European water vole in the study area in the years 1957-1999 (A) and 20002017 (B) and of sites, where the rodent was not found in large samples of the owls' food (at least 100 vertebrate prey items in each) collected in the years 1980-2017 (C).

\section{DISCUSSION}

Comparison of localities of the European water vole found so far with those, where the species was not recorded indicates, that in areas situated within a radius of $120 \mathrm{~km}$ from Warsaw the rodent is rare and distributed unevenly. Kampinos Forest is one of a few larger refugia, in which the species is relatively numerous (Lesiński et al. 2013). The species was also recorded in Kozienice Forest (Zub 2017), but its numbers in the area is hard to assess. It is 
absent from many forest complexes, even those with larger wetlands. Examples of the latter are areas such as: Bolimowska Forest (Lesiński et al. 2016a) or Mazovian Landscape Park with areas between Rembertów and Okuniew (Lesiński et al. 2016c).

The European water vole is more common in Mazurian Lakeland, in northern Podlasie (Kowalski \& Lesiński 1988, Gryz et al. 2011a, Zub 2017), and also in western part of the country (Zub 2017). It is common in central Poland, even in areas with a small part of open waters and wetlands like e.g. Wieluń Upland (Lesiński 1991). Water voles (probably representing montane water vole) are frequent in the diet of owls in surrounding of Cracow (Bocheński Jr 1990, Lesiński \& Stolarz 2012) and Przemyśl (Cais 1963), and in the Beskid Niski (Kulczycki 1964) or the Beskid Wyspowy (Ruprecht 2002). In some of these places the species seems to be numerous as evidenced by its big share in the diet of owls (Table 2).

Table 2. Percentage share of water voles (Arvicola amphibius or A. scherman) in the food of owls in area inhabited by its largest population in Mazowsze (Kampinos Forest) and in some areas of southern Poland; Ao - Asio otus, Sa - Strix aluco, Ta - Tyto alba

\begin{tabular}{lccccl}
\hline Study area & $\begin{array}{c}\text { Years of } \\
\text { studies }\end{array}$ & $\begin{array}{c}\text { Owl } \\
\text { species }\end{array}$ & $\begin{array}{c}\text { Number of vertebrate } \\
\text { prey items }\end{array}$ & $\begin{array}{c}\text { Percent of Arvicola } \\
\text { amphibius }\end{array}$ & References \\
\hline Kampinos Forest & $1980-2012$ & Sa & 11,235 & 0.5 & Lesiński et al. 2013 \\
Kampinos Forest & $1983-2013$ & Ao & 1,109 & 0.2 & Lesiński et al. 2016b \\
Wieluń Upland & $1983-1988$ & Ta & 21,839 & 0.2 & Lesiński 1991 \\
Paszkówka near Cracow & $2007-2011$ & Sa & 229 & 7.9 & Lesiński \& Stolarz 2012 \\
Cracow suburbia & $1984-1986$ & Sa & 1,344 & 4.5 & Bocheński Jr 1990 \\
Beskid Wyspowy & 1996 & Sa & 224 & 9.3 & Ruprecht 2002 \\
Bytom & $2011-2016$ & Sa & 391 & 1.5 & Lesiński \& Beuch 2016 \\
Niepołomicka Forest & $1978-1979$ & Sa & 474 & 0.8 & Wasilewski 1990 \\
Beskid Niski & $1960-1961$ & Sa & 267 & 8.2 & Kulczycki 1964 \\
Beskid Niski & $1960-1961$ & Ta & 3,332 & 3.2 & Kulczycki 1964 \\
Surroundings of Przemyśl & $1958-1962$ & Sa & 718 & 6.0 & Cais 1963 \\
Surroundings of Przemyśl & $1958-1962$ & Ta & 5,813 & 7.1 & Cais 1963 \\
Silesia & $1977-1981$ & Ta & $19,525 *$ & 0.8 & Sałata-Piłacińska 1994 \\
\hline
\end{tabular}

It is probable, however, that the number of the European water vole in Poland, especially in northern and central parts of the country, has recently decreased due to expansion of the American mink Neovison vison (Schreber, 1777). Antagonistic relationships of the two species were described for some western European countries (Saucy 1999, Battersby 2005). Although there is not much evidence from our study area, possible decrease of the number of the European water vole could resulted in the extinction of its smaller populations and such were present in some regions of Mazowsze. Findings from several sites, where studies lasted long enough (Bogate, Mława, Kępa Kiełpińska), might confirm a declining trend in populations of the European water vole in recent decades.

The used study method - analysing of owl pellets - gives some limitations in detecting species connected with specific water habitats. Moreover, the European water vole shows cyclic fluctuations in numbers (Litvinov et al. 2013), and in smaller samples of owl pellets collected in years with low vole abundance the probability of its occurrence is low. It is not excluded that in some part of the study area, especially in the north, isolated populations not detected in this study still exist.

There is a need of intensifying studies on the distribution of this species in central Poland to assess whether declining trend is real and causes further decrease of the number of animals. Since observations of individuals might be burdened with error - possible confusing the European water vole with the common rat Rattus norvegicus (Berkenhout, 1769) or muskrat Ondatra zibethicus (Linnaeus, 1766) - it is best to apply the trap method or the analysis of owl pellets. 


\section{ACKNOWLEDGEMENTS}

Authors are grateful to many persons for help in collecting study material, in particular to: Jerzy Borowski, Sławomir Chmielewski, Andrzej Dombrowski, Piotr Jabłoński, Ireneusz Krasnodębski, Bogumiła Olech, Paweł Pawlikowski, Maciej Rębiś, Mirosław Rzępała, Jacek Tabor, Jan Zduńczyk and to students of the Field Biologists Circle, Cardinal Stefan Wyszyński University. Thanks are also due to Karol Zub for providing details of findings presented in the Atlas of Polish Mammals, and two referees for their valuable comments.

\section{REFERENCES}

BABIŃSKA J. 1972. Estimation of rodent consumption in a meadow ecosystem belonging to the community of Molinietalia order. Ekologia Polska Ser. A 20: 747-761.

BARDZIŃSKA M. 2016. Skład pokarmu sympatrycznie występujących gatunków sów na Wysoczyźnie Mławskiej [Food composition of sympatric species of owls inhabiting in Wysoczyzna Mławska]. Master Thesis, Cardinal Stefan Wyszyński University, Faculty of Biology and Environment, Warszawa. [In Polish with English summary]

BARTOSZ G. \& MARKOWSKI J. 1972. Fauna Niebieskich Źródeł. Materiały do fauny ssaków (Mammalia) [Fauna of Niebieskie Źródła (the Nature Reserve of Blue Springs). Materials to the mammal fauna]. Zeszyty Naukowe Uniwersytetu Łódzkiego. Nauki matematyczno-przyrodnicze, ser. 2, 46: 111-114. [In Polish with English summary]

BATTERSBY J. (ed.) 2005. UK mammals: species status and population trends. First report by the Tracking Mammals Partnership. JNCC/Tracking Mammals Partnership, Peterborough, 116 pp.

BoCHEŃSKi JUN. Z. 1990. The food of suburban tawny owls on the background of birds and mammals occurring in the hunting territory. Acta Zoologica Cracoviensia 33: 149-171.

CAIS L. 1963. Badania nad składem pokarmu kilku gatunków sów [A study on the food composition of a few species of owls]. Zeszyty Naukowe Uniwersytetu im. Adama Mickiewicza w Poznaniu 44, Biologia 4: 3-21. [In Polish]

CAIS L. 1974. Investigation on morphology and geographical distribution of water-voles Arvicola terrestris L. 1758 in Poland. PTPN, Prace Komisji Biologicznej, 37: 1-30. [In Polish with English summary]

CAssola F. 2016. Arvicola scherman. (errata version published in 2017) The IUCN Red List of Threatened Species 2016: e.T136766A115519839

GrYZ J., GóźDŹ I. \& KRAUZE-GRYZ D. 2011a. Impact of anthropogenic landscape transformation on the diet composition of tawny owl Strix aluco L. in Biebrza National Park. Parki Narodowe i Rezerwaty Przyrody 30, 3-4: 109-118. [In Polish with English abstract]

GRYZ J. \& KRAUZE-GRYZ D. 2015. Seasonal variability in the diet of the long-eared owl Asio otus in a mosaic of field and forest habitats in central Poland. Acta Zoologica Cracoviensia 58: 173-180; DOI: 10.3409/azc.58_2.173

GRYZ J. \& KRAUZE-GRYZ D. 2016a. Vertebrates in the diet of tawny owl Strix aluco in Lipce Forest (Rogów Forest District). Parki Narodowe i Rezerwaty Przyrody 35 (3): 89-96. [In Polish with English abstract]

Gryz J. \& Krauze-Gryz D. 2016b. Diet composition of long-eared owl Asio otus nesting in the area of Głuchów commune (central Poland). Kulon 21: 107-109. [In Polish with English summary]

GRYZ J., KRAUZE D. \& GOSZCZYŃSKi J. 2008. The small mammals of Warsaw as inferred from tawny owl (Strix aluco) pellet analyses. Annales Zoologici Fennici 45: 281-285; DOI: 10.5735/086.045.0407

GrYZ J., KRAUZE-GRYZ D. \& LESIŃSKI G. 2011b. Mammals in the vicinity of Rogów (central Poland). Fragmenta Faunistica 54: 183-197; DOI: 10.3161/00159301FF2011.54.2.183

GryZ J., LesiŃSKi G., KRAUZE-Gryz D. \& StOlarZ P. 2017. Protected forest areas within urban agglomeration as important refuges of small mammal communities. Folia Forestalia Polonica 59: 3-13; DOI: 10.1515/ffp-20170001

KOWALSKI M. \& LESIŃSKI G. 1986. Small mammal fauna in Janowo (Warsaw voivodship) based on the analysis of Barn owl (Tyto alba Scop.) pellets. Przegląd Zoologiczny 30: 327-331. [In Polish with English summary]

KOWALSKI M. \& LESIŃSKI G. 1988. Drobne ssaki w pokarmie puszczyka Strix aluco znad jeziora Łuknajno. Chrońmy Przyrodę Ojczystą 44, 4: 80-82. [In Polish with English abstract and summary]

KulCZYCKI A. 1964. Study on the make up of the diet of owls from the Niski Beskid Mts. Acta Zoologica Cracoviensia 9: 529-556. [In Polish with English summary]

LEsIŃSKI G. 1991. The diet of the barn owl, Tyto alba (Scop.) on the Wieluń Upland. Lubuski. Lubuski Przegląd Przyrodniczy 2, 4: 29-35. [In Polish with English summary]

LESIŃSKI G. 2016. Small mammals of „Dębina I” reserve in the eastern Masovia on the basis of food composition of Tawny Owls. Kulon 21: 41-47. [In Polish with English abstract]

LESIŃSKI G. \& BEUCH S. 2016. Small mammal community in suburban forests of Bytom based on the analysis of Tawny Owl’s Strix aluco diet. Kulon 21: 31-39. [In Polish with English summary] 
LEsiŃSKi G., BŁACHOwsKi G. \& SIUCHNO M. 2009. Vertebrates in the diet of the tawny owl Strix aluco in northern Podlasie (NE Poland) - comparison of forest and rural habitats. Fragmenta Faunistica 52: 51-59; DOI: 10.3161/00159301FF2009.52.1.051

LESIŃSKI G. \& GRYZ J. 2012. How protecting a suburban forest as a natural reserve effected small mammal communities. Urban Ecosystems 15: 103-110; DOI: 10.1007/s11252-011-0190-7

LEsiŃSKi G., GrYZ J. \& KRAUZE-GrYZ D. 2014. Small mammals of the Landscape-Nature Protected Complex "Mroga Valley” based on analysis of tawny owl Strix aluco pellets. Parki Narodowe i Rezerwaty Przyrody 33: 88-93. [In Polish with English abstract]

LesińsKi G., JANUs K., NowAK K. \& PruszKowsKa A. 2016a. Small mammmals of the Bolimowski Landscape Park and surrounding based on analysis of tawny owl Strix aluco diet. Parki Narodowe i Rezerwaty Przyrody 35, 4: 5769. [In Polish with English abstract]

LESIŃSKI G., ROMANOWSKI J. \& BUDEK S. 2016b. Winter diet of the long-eared owl Asio otus in various habitats of central and north-eastern Poland. Annals of Warsaw University of Life Sciences - SGGW. Animal Science 55, 1: 81-88.

Lesiński G., Romanowski J., Gryz J., Olszewski A., Kowalski M., KrauZe-Gryz D., Olech B., PePŁowsKaMARCZAK D. \& TARŁowSKi A. 2013. Small mammals of Kampinos National Park and its protection zone, as revealed by analyses of the diet of tawny owls Strix aluco. Fragmenta Faunistica 56: 65-81; DOI: 10.3161/00159301FF2013.56.1.065

LesiŃSKI G. \& StOlaRz P. 1999. Vertebrates in the diet of the tawny owl, Strix aluco in the Sobieski Forest on Warsaw borders. Kulon 1-2: 77-81. [In Polish with English summary]

LESIŃSKi G. \& STOLARZ P. 2012. Small mammals in pellets of the tawny owl Strix aluco from the village of Paszkówka near Cracow. Chrońmy Przyrodę Ojczystą 68: 109-113. [In Polish with English abstract and summary]

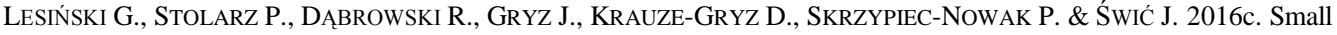
mammals in the diet of owls in the Masovian Landscape Park and in adjacent areas. Fragmenta Faunistica 59: 73-86; DOI: 10.3161/00159301FF2013.59.2.073

Litvinov Yu. N., Kovaleva V. Yu., Efimov V. M. \& GalaKtionov YU. K. 2013. Cyclicity of the European water vole population as a factor of biodiversity in ecosystems of Western Siberia. Russian Journal of Ecology 44: 422-427; DOI: $10.1134 / \mathrm{S} 1067413613050081$

RACZYŃSKi J. 1983. Arvicola terrestris (Linnaeus, 1758). In: Pucek Z. \& Raczyński J. (eds). Atlas rozmieszczenia ssaków Polski. PWN, Warsaw: 106-108.

RomANOWSKi J. 1988. Trophic ecology of Asio otus (L.) and Athene noctua (Scop.) in the suburbs of Warsaw. Polish Ecological Studies 14 (1-2): 223-234.

ROMANOWSKI J., LESIŃSKI G.\& BARDZIŃSKA M. 2016. Small mammals of Warsaw suburban areas (central Poland) in the diet of the Tawny owl Strix aluco. Studia Ecologiae et Bioethicae 15: 105-113. [In Polish with English summary]

RomANOWSKi J., TARŁowsKi A., LesiŃSKi G. \& OlSZEWSKi A. 2014. Small mammals of Chojnowski Landscape Park in the diet of the tawny owl Strix aluco. Chrońmy Przyrodę Ojczystą 70: 63-67. [In Polish with English abstract and summary]

ROMANOWSKI J. \& ŻMIHORSKI M. 2008. Effect of season, weather and habitat on diet variation of a feeding-specialist: a case study of the long-eared owl, Asio otus in Central Poland. Folia Zoologica 57: 411-419.

RupRECHT A. L. 2002. Skład pokarmu puszczyka zwyczajnego Strix aluco L. z Beskidu Wyspowego (Dobra k. Limanowej). Przegląd Przyrodniczy 13, 1-2: 191-197.

SAŁATA-PIŁACIŃSKA B. 1994. Mammal fauna of Silesia in pellets of the barn owl Tyto alba (Scopoli, 1769). Badania Fizjograficzne nad Polską Zachodnią 41, seria C, Zoologia: 61-79. [In Polish with English summary]

SAucy F. 1999. Arvicola terrestris. In: Mitchell-Jones A. J., AmORi G., Bogdanowicz W., KRYŠTUFEK B., Reijnders P. J. H., Spitzenberger F., StubBe M., Thissen J. M. B., VohralíK V. \& ZiMA J. (eds). The Atlas of European Mammals. London, UK: Academic Press: 222-223.

STOLARZ P. \& LESIŃSKi G. 2012. Vertebrates in diet of Tawny Owl Strix aluco in nature reserve „Bagno Jacka” and surrounding area. Kulon 17: 107-110. [In Polish with English abstract]

STOLARZ P. \& LESIŃSKi G. 2015. Winter and spring diet of long-eared owl in lower Pilica the valley. Parki Narodowe i Rezerwaty Przyrody 34, 4: 92-96. [In Polish with English abstract]

StOlARZ P., StOlARZ J. \& LESIŃSKI G. 2017. Seasonal changes In the diet of the long-eared owl Asio otus in the lower Pilica River valley. Przegląd Przyrodniczy 28, 1: 101-106. [In Polish with English abstract]

URBANEK A. 2004. Zróżnicowanie składu pokarmu płomykówki (Tyto alba) na terenie Polski środkowo-wschodniej [Diet of the Barn owl (Tyto alba) in central-eastern Poland]. Master Thesis, Akademia Podlaska, Siedlce. [In Polish with English summary]

WASILEWSKI J. 1990. Dynamics of the abundance and consumption of birds of prey in the Niepołomice Forest. Acta Zoologica Cracoviensia 33: 173-213.

ZUB K. 2017. Karczownik Arvicola terrestris (Linnaeus, 1758). In: OKARMA H. et al. (eds) Atlas ssaków Polski. http://www.iop.krakow.pl/ssaki/Gatunek.aspx?spID=66 (20 Apr 2017) 


\section{STRESZCZENIE}

[Rozmieszczenie karczownika ziemnowodnego Arvicola amphibius (Linnaeus, 1758) na Mazowszu i południowym Podlasiu]

W pracy przedstawiono rozmieszczenie karczownika ziemnowodnego Arvicola amphibius na Mazowszu i południowym Podlasiu, na terenach zlokalizowanych w promieniu ok. $120 \mathrm{~km}$ od Warszawy. Zestawiono opublikowane dotąd dane oraz niepublikowane wyniki pochodzące $\mathrm{z}$ analiz diety trzech pospolitych gatunków sów: płomykówki Tyto alba, puszczyka Strix aluco i uszatki Asio otus. Gryzoń ten na terenie badań jest rzadki (Tab. 1, Ryc.), zwłaszcza w porównaniu z zachodnią i skrajnie północną Polską. Na południu kraju udziały karczowników (w większości prawdopodobnie reprezentujących gatunek $A$. scherman) w diecie sów są wyraźnie większe niż na Mazowszu i południowym Podlasiu (Tab. 2). Najwięcej stanowisk karczownika ziemnowodnego stwierdzono w Puszczy Kampinoskiej, gdzie aktualnie występuje prawdopodobnie największa jego populacja w tej części Polski. Poza tym kompleksem leśnym stwierdzany był bardzo lokalnie, a w latach 2000-2017 znanych było tylko kilkanaście stanowisk (Tab. 1). Nie występuje nawet na dużych terenach, bogatych w różne zbiorniki wodne, np. w Mazowieckim i Chojnowskim Parku Krajobrazowym, Puszczy Bolimowskiej. Rzadkość karczownika ziemnowodnego potwierdzają dane z 235 dużych prób pokarmu sów (przynajmniej po 100 ofiar kręgowych każda) (Appendix), w których nie wykazano obecności tego gatunku. Były one rozmieszczone dość równomiernie na Mazowszu i południowym Podlasiu (Ryc.). 


\section{APPENDIX}

The list of sites within a 120-kilometre radius from Warsaw, where samples of the owls' diet containing at least 100 vertebrate prey items but not the European water vole was collected. Ao - Asio otus, Sa - Strix aluco, Ta - Tyto alba, KNP - Kampinos National Park

\begin{tabular}{|c|c|c|c|c|}
\hline Site & $\begin{array}{c}\text { Owl } \\
\text { species }\end{array}$ & $\begin{array}{l}\text { Study } \\
\text { years }\end{array}$ & $\begin{array}{l}\text { Sample } \\
\text { size }\end{array}$ & Source of data \\
\hline Baboszewo & Ta & 2000 & 428 & Unpublished data \\
\hline Baboszewo & Ao & 2016-2017 & 515 & Unpublished data \\
\hline Bagno Jacka, Warsaw Wesoła & $S a$ & $2011-2016$ & 1,426 & $\begin{array}{l}\text { Stolarz \& Lesiński 2012, Lesiński et al. } \\
\text { 2016c, unpublished data }\end{array}$ \\
\hline Bagno Śmiardki, Zielonka & $S a$ & 2013-2016 & 116 & Lesiński et al. 2016c \\
\hline Bażantarnia & $S a$ & 2016 & 302 & Unpublished data \\
\hline Bądkowo Kościelne & $\mathrm{Ta}$ & 2003-2004 & 592 & Unpublished data \\
\hline Belsk Duży & Ao & 1992-1993 & 661 & Unpublished data \\
\hline Biała Rawska & $\mathrm{Ta}$ & 1989-1991 & 121 & Unpublished data \\
\hline Białynin near Rawa Mazowiecka & Ao & $2016-2017$ & 283 & Unpublished data \\
\hline Bielsk near Płock & $\mathrm{Ta}$ & 1989-2016 & 571 & Unpublished data \\
\hline Bielsk near Płock & Ao & 2016-2017 & 1,417 & Unpublished data \\
\hline Bodzanów & Ao & 2016-2017 & 138 & Unpublished data \\
\hline Bogate & $\mathrm{Ta}$ & 1991-2009 & 2,126 & Unpublished data \\
\hline Boglewice near Grójec & $\mathrm{Ta}$ & 1993 & 1,769 & Unpublished data \\
\hline Bogurzyn & $\mathrm{Ta}$ & 1999 & 100 & Unpublished data \\
\hline Bogusławice near Płońsk & $\mathrm{Ta}$ & 2004 & 149 & Unpublished data \\
\hline Borowie & $\mathrm{Ta}$ & 1994 & 277 & Unpublished data \\
\hline Brzeźce & Ao & 2012-2017 & 5,270 & $\begin{array}{l}\text { Stolarz \& Lesiński 2015, Stolarz et al. } \\
\text { 2017, unpublished data }\end{array}$ \\
\hline Brzeźce & $S a$ & 2005-2016 & 291 & Unpublished data \\
\hline Buchnik near Jabłonna & $S a$ & 2007-2017 & 1,615 & Unpublished data \\
\hline Budy Sułkowskie & $\mathrm{Sa}$ & 1993-1998 & 135 & Unpublished data \\
\hline Bulkowo & Ao & 2016-2017 & 362 & Unpublished data \\
\hline Byliny Stare & Sa & 2016 & 149 & Unpublished data \\
\hline Całowanie & Ao & 1984-2016 & 434 & Lesiński et al. 2016c, unpublished data \\
\hline Celestynów & $S a$ & 2014-2016 & 274 & Lesiński et al. 2016c \\
\hline Ceranów & Sa & 2009-2014 & 164 & Unpublished data \\
\hline Ceranów & $\mathrm{Ta}$ & 1994-1996 & 1,075 & Unpublished data \\
\hline Chorzele & $\mathrm{Ta}$ & 1991 & 109 & Unpublished data \\
\hline Ciechanów & Ao & 2017 & 470 & Unpublished data \\
\hline Cieksyn & $\mathrm{Ta}$ & 1985 & 161 & Unpublished data \\
\hline Cybulice Duże & $S a$ & 2000 & 316 & Unpublished data \\
\hline Czarnocin & $\mathrm{Ta}$ & 2016 & 607 & Unpublished data \\
\hline Czerwińsk, Vistula river & $S a$ & 2011 & 120 & Unpublished data \\
\hline Czerwonka Liwska & $\mathrm{Ta}$ & 1990 & 293 & Unpublished data \\
\hline Dłużew & $S a$ & 2015-2016 & 240 & Lesiński et al. 2016c \\
\hline Doliska near Rogów & $S a$ & 2004-2011 & 103 & Gryz et al. 2011b, unpublished data \\
\hline Drewnica Forest District, division 23 & $S a$ & 1997 & 118 & Lesiński et al. $2016 \mathrm{c}$ \\
\hline Drewnica Forest District, division 68 & $\mathrm{Sa}$ & 1997-1999 & 114 & Lesiński et al. 2016c \\
\hline Drwalew near Grójec & $\mathrm{Ta}$ & 1992 & 280 & Unpublished data \\
\hline Dziecinów & Ao & 1984-1990 & 334 & Unpublished data \\
\hline Dziekanów Leśny (KNP) & Sa & $1982-2007$ & 274 & Unpublished data. \\
\hline Dzięcioły Kolonia & $S a$ & 2011-2014 & 622 & Unpublished data \\
\hline Garwolin & Ao & $1989-1990$ & 359 & Unpublished data \\
\hline Głowaczów & $\mathrm{Ta}$ & 1992 & 880 & Unpublished data \\
\hline Głuchów & $\mathrm{Ta}$ & 1989 & 952 & Unpublished data \\
\hline Goniwilk Nowy & Ao & 1988-1997 & 1,253 & Unpublished data \\
\hline Goszczyn & $\mathrm{Ta}$ & 1992 & 940 & Unpublished data \\
\hline Goworowo & $\mathrm{Ta}$ & 1999 & 817 & Unpublished data \\
\hline Góra near Płock & Ao & 2016-2017 & 137 & Unpublished data \\
\hline Góra Raabego (KNP) & Ao & 1995 & 169 & Romanowski \& Żmihorski 2008 \\
\hline Górki near Rogów & $\mathrm{Sa}$ & $2003-2011$ & 169 & Gryz et al. 2011b, unpublished data \\
\hline Grębków near Węgrów & $\mathrm{Ta}$ & 1990 & 184 & Unpublished data \\
\hline
\end{tabular}


G. Lesiński et al.

\begin{tabular}{|c|c|c|c|c|}
\hline Grodkowo near Wyszogród & $\mathrm{Sa}$ & 2013 & 210 & Unpublished data \\
\hline Grudusk & $\mathrm{Ta}$ & 1991 & 416 & Unpublished data \\
\hline Gulin near Radom & Ao & 1988-1992 & 1,142 & Unpublished data \\
\hline Gumino near Płońsk & $\mathrm{Ta}$ & 1990 & 1,179 & Unpublished data \\
\hline Jabłonna & $\mathrm{Sa}$ & 2007-2013 & 1,033 & Unpublished data \\
\hline Jabłonna rez. & $\mathrm{Sa}$ & 2010-2016 & 687 & Unpublished data \\
\hline Jankowice near Jedlińsk & $\mathrm{Ta}$ & 1992 & 110 & Unpublished data \\
\hline Janowo & $\mathrm{Ta}$ & 1980-1984 & 7,797 & Kowalski \& Lesiński 1986 \\
\hline Jarczew & Ao & 1991-1992 & 1,897 & Unpublished data \\
\hline Jasień & $\mathrm{Sa}$ & 2005-2011 & 151 & Gryz et al. 2011b, unpublished data \\
\hline Jedlińsk & $\mathrm{Ta}$ & 1992 & 821 & Unpublished data \\
\hline Jegiel rez. near Łochów & $S a$ & 1988-2016 & 110 & Unpublished data \\
\hline Jeleniec & $\mathrm{Ta}$ & 1992 & 645 & Unpublished data \\
\hline Jeruzal & $\mathrm{Ta}$ & 1990-2001 & 128 & Unpublished data \\
\hline Kamionka near Latowicz & $\mathrm{Ta}$ & 2000 & 403 & Unpublished data \\
\hline Kaszów & $\mathrm{Ta}$ & 1992 & 249 & Unpublished data \\
\hline Kębłów Nowy & Ao & 1989-1993 & 490 & Unpublished data \\
\hline Kępa Kiełpińska near Łomianki & Ao & 1995-1996 & 638 & $\begin{array}{l}\text { Romanowski \& Żmihorski 2008, } \\
\text { unpublished data }\end{array}$ \\
\hline Kiełpiniec & $\mathrm{Ta}$ & 1999-2009 & 301 & Unpublished data \\
\hline Kiernozia & $\mathrm{Ta}$ & 1991 & 1,932 & Unpublished data \\
\hline Kleczkowo near Ostrołęka & $\mathrm{Ta}$ & 1990-1991 & 104 & Unpublished data \\
\hline Klembów, rez. „Dębina I” & $\mathrm{Sa}$ & 1991-2017 & 2,714 & Lesiński 2016, unpublished data \\
\hline Klimonty near Mordy & Ao & 1987-1993 & 609 & Unpublished data \\
\hline Kołacin near Rogów & Sa & 2012-2013 & 226 & Lesiński et al. 2014 \\
\hline Kołbiel & $\mathrm{Ta}$ & 1990-2001 & 1,029 & Unpublished data \\
\hline Kompna near Łowicz & $\mathrm{Ta}$ & 1988-1991 & 3,238 & Unpublished data \\
\hline Konstancin Jeziorna & $S a$ & 2010-2012 & 332 & Romanowski et al. 2014, unpublished data \\
\hline Korytnica near Trojanów & $\mathrm{Ta}$ & 1990 & 429 & Unpublished data \\
\hline Korytnica near Węgrów & $\mathrm{Ta}$ & 1990 & 360 & Unpublished data \\
\hline Kostrzyn near Białobrzegi & $\mathrm{Ta}$ & 1992 & 2,801 & Unpublished data \\
\hline Kozienice & Ao & 1992-1998 & 112 & Unpublished data \\
\hline Krasne & $\mathrm{Ta}$ & 2002 & 313 & Unpublished data \\
\hline Kraśnicza Wola & $\mathrm{Sa}$ & 2011-2015 & 341 & Romanowski et al. 2016 \\
\hline Krysk near Naruszewo & Ao & 1996 & 1,301 & Unpublished data \\
\hline Krzesk near Siedlce & $\mathrm{Ta}$ & 1990 & 591 & Unpublished data \\
\hline Krześlin near Suchożebry & $\mathrm{Ta}$ & 1990 & 253 & Unpublished data \\
\hline Krzynowłoga Mała & $\mathrm{Ta}$ & 1990-2000 & 319 & Unpublished data \\
\hline Krzywa Góra (KNP) & $\mathrm{Sa}$ & 1989-2007 & 616 & Lesiński et al. 2013, unpublished data \\
\hline Kuczbork & $\mathrm{Ta}$ & 1999 & 421 & Unpublished data \\
\hline Kuczki near Radom & $\mathrm{Ta}$ & 1993 & 570 & Unpublished data \\
\hline Kuflew near Mrozy & $\mathrm{Ta}$ & 1990 & 230 & Unpublished data \\
\hline Kuligów & Ao & 2010-2012 & 449 & Lesiński et al. $2016 b$ \\
\hline Kurdwanów & $\mathrm{Ta}$ & 1993 & 104 & Unpublished data \\
\hline Kurowice near Sabnie & $\mathrm{Ta}$ & 1990 & 272 & Unpublished data \\
\hline Lasek & Ao & 2004-2007 & 218 & Gryz \& Krauze-Gryz 2015 \\
\hline Laski Forest District, division 1 (KNP) & $\mathrm{Sa}$ & 1982-1984 & 164 & Unpublished data \\
\hline Laski Forest District, division 139 (KNP) & Ao & 1993 & 258 & Unpublished data \\
\hline Laski Forest District, division 167 (KNP) & Ao & 1999 & 210 & Unpublished data \\
\hline Latowicz & $\mathrm{Ta}$ & 1990-2001 & 250 & Unpublished data \\
\hline Lelice & Sa & 2013-2017 & 304 & Unpublished data \\
\hline Lipce & $S a$ & 2013-2016 & 1,425 & Gryz \& Krauze-Gryz 2016a \\
\hline Lisna near Skierniewice & Sa & 2014-2016 & 746 & Lesiński et al. 2016a \\
\hline Liw & $\mathrm{Ta}$ & 1990-1997 & 471 & Unpublished data \\
\hline Łęgonice Nowe near Grójec & $\mathrm{Ta}$ & 1992 & 642 & Unpublished data \\
\hline Łomianki & Ao & 1986-1990 & 1,090 & Unpublished data \\
\hline Magnuszew & $S a$ & 1992-2002 & 870 & Unpublished data \\
\hline Maków Mazowiecki & $\mathrm{Ta}$ & 1985 & 1,386 & Unpublished data \\
\hline Małkinia Górna & $\mathrm{Ta}$ & 2000 & 707 & Unpublished data \\
\hline Michałowice & Ao & 2016-2017 & 1,452 & Unpublished data \\
\hline Miedzna near Węgrów & $\mathrm{Ta}$ & 1990 & 479 & Unpublished data \\
\hline
\end{tabular}




\begin{tabular}{|c|c|c|c|c|}
\hline Mikanów & Sa & $2015-2017$ & 106 & Unpublished data \\
\hline Mława, surroundings & $\mathrm{Ta}$ & 2015-2016 & 412 & Bardzińska 2016 \\
\hline Mława, surroundings & Ao & 2015-2016 & 1,341 & Bardzińska 2016 \\
\hline Mogielnica near Grójec & $\mathrm{Ta}$ & 1993 & 132 & Unpublished data \\
\hline Mokobody & Sa & 2013 & 184 & Unpublished data \\
\hline Mołożew & Ao & 1992 & 107 & Unpublished data \\
\hline Morszków near Jabłonna Lacka & $\mathrm{Ta}$ & 1990 & 192 & Unpublished data \\
\hline Mroków near Trojanów & Ao & 1991-1995 & 603 & Unpublished data \\
\hline Natolin near Nur & Sa & 2004-2017 & 1,591 & Unpublished data \\
\hline Nowe Miasto near Płońsk & $\mathrm{Ta}$ & 1992 & 119 & Unpublished data \\
\hline Nowy Duninów & $\mathrm{Ta}$ & 1989-2003 & 342 & Unpublished data \\
\hline Nowy Dwór Mazowiecki & Sa & 1991-2017 & 319 & Unpublished data \\
\hline Nur & $\mathrm{Ta}$ & 1995-1998 & 604 & Unpublished data \\
\hline Opinogóra Górna & $\mathrm{Ta}$ & 1992 & 484 & Unpublished data \\
\hline Osmolin near Kiernozia & $\mathrm{Ta}$ & 1991 & 596 & Unpublished data \\
\hline Ostrówek, Vistula river & Sa & 2013 & 211 & Unpublished data \\
\hline Otwock & Sa & 2004-2016 & 263 & Lesiński et al. 2016c \\
\hline Parysów near Garwolin & $\mathrm{Ta}$ & 1990-2000 & 920 & Unpublished data \\
\hline Paśniki near Skierniewice & $\mathrm{Sa}$ & 2014 & 123 & Lesiński et al. 2016a \\
\hline Piotrowice & Ao & 1984-1990 & 858 & Unpublished data \\
\hline Płoniawy Bramura & $\mathrm{Ta}$ & 1985 & 407 & Unpublished data \\
\hline Pniewnik near Węgrów & $\mathrm{Ta}$ & 1990 & 100 & Unpublished data \\
\hline Pniewo Wielkie & $\mathrm{Sa}$ & 1998-2000 & 808 & Unpublished data \\
\hline Podkowa Leśna & Sa & 2010-2014 & 110 & Romanowski et al. 2016, unpublished data \\
\hline Ponurzyca & Sa & 2002 & 264 & Lesiński et al. $2016 \mathrm{c}$ \\
\hline Popień & Ao & 2009-2011 & 112 & Gryz \& Krauze-Gryz 2015 \\
\hline Poświętne Jedlińskie near Pionki & $\mathrm{Ta}$ & $1990-1991$ & 173 & Unpublished data \\
\hline Prusy & Ao & 2014-2015 & 320 & Gryz \& Krauze-Gryz 2016b \\
\hline Pruszków & Sa & 2010 & 126 & Romanowski et al. 2016 \\
\hline Pruszyn near Siedlce & $\mathrm{Ta}$ & 1985-2000 & 557 & Unpublished data \\
\hline Przasnysz & $\mathrm{Ta}$ & 1985-1991 & 4,110 & Unpublished data \\
\hline Przyłęk Duży near Rogów & Ao & 2004-2007 & 218 & Gryz \& Krauze-Gryz 2015 \\
\hline Pszczonów & Sa & 2014-2016 & 306 & Unpublished data \\
\hline Pulwy & Ao & 1989-1990 & 124 & Unpublished data \\
\hline Pustki near Siedlce & Ao & 1988 & 226 & Unpublished data \\
\hline Radzików Wielki near Mordy & $\mathrm{Ta}$ & 1987-1991 & 1,614 & Unpublished data \\
\hline Rawa Mazowiecka & $\mathrm{Ta}$ & 1988-1989 & 951 & Unpublished data \\
\hline Rogów & Sa & 2011-2013 & 247 & Lesiński et al. 2014 \\
\hline Rosochate Kościelne & $\mathrm{Ta}$ & 1999 & 433 & Unpublished data \\
\hline Rościszewo near Sierpc & $\mathrm{Ta}$ & 1989 & 108 & Unpublished data \\
\hline Ruda near Mińsk Mazowiecki & Sa & 2013-2017 & 271 & Lesiński et al. 2016c \\
\hline Ruda near Skierniewice & Sa & $2015-2016$ & 165 & Lesiński et al. 2016a \\
\hline Samogoszcz & $\mathrm{Ta}$ & 1991-1999 & 860 & Unpublished data \\
\hline Secymin, Vistula river & Sa & 2012 & 136 & Unpublished data \\
\hline Seroczyn & Sa & 1994-1998 & 598 & Unpublished data \\
\hline Sękocin & Sa & 2007-2017 & 329 & Unpublished data \\
\hline Siecień near Płock & $\mathrm{Ta}$ & 1989-2004 & 984 & Unpublished data \\
\hline Siedlce & Ao & 1994 & 285 & Unpublished data \\
\hline Sikórz near Płock & $\mathrm{Ta}$ & 1988-2004 & 114 & Unpublished data \\
\hline Słubice & $\mathrm{Ta}$ & 1991 & 561 & Unpublished data \\
\hline Sobienie Biskupie & Ao & 1984-1990 & 121 & Unpublished data \\
\hline Sobienie Kiełczewskie & Ao & 1984 & 105 & Unpublished data \\
\hline Sobienie Szlacheckie & Ao & 1984 & 131 & Unpublished data \\
\hline Sobieszyn near Ryki & $\mathrm{Ta}$ & 1991 & 332 & Unpublished data \\
\hline Sobowo near Płock & $\mathrm{Ta}$ & 1989-2004 & 465 & Unpublished data \\
\hline Soczewka & $\mathrm{Ta}$ & 1989 & 397 & Unpublished data \\
\hline Sokolniki near Żelechów & Ao & 1993 & 155 & Unpublished data \\
\hline Sowia Wola Folwarczna & Sa & 1997-2006 & 1,285 & Lesiński et al. 2013, unpublished data \\
\hline Stanin & $\mathrm{Ta}$ & $1991-2000$ & 929 & Unpublished data \\
\hline Staroźreby & $\mathrm{Ta}$ & 2016 & 107 & Unpublished data \\
\hline Sterdyń & $\mathrm{Ta}$ & 1990-1994 & 692 & Unpublished data \\
\hline
\end{tabular}




\begin{tabular}{|c|c|c|c|c|}
\hline Stoczek near Węgrów & $\mathrm{Ta}$ & 1990-2001 & 273 & Unpublished data \\
\hline Stok Lacki near Siedlce & Ao & 1988-1992 & 697 & Unpublished data \\
\hline Strzyżew near Łuków & Ao & 1989 & 235 & Unpublished data \\
\hline Studzieniec & $S a$ & 2014 & 322 & Lesiński et al. 2016a \\
\hline Szczałb & $\mathrm{Ta}$ & 1999-2000 & 1,017 & Unpublished data \\
\hline Szreńsk & $\mathrm{Ta}$ & 1999 & 615 & Unpublished data \\
\hline Szymanów near Sochaczew & $\mathrm{Ta}$ & 1991 & 811 & Unpublished data \\
\hline Tustań near Naruszewo & $S a$ & 2004-2008 & 1,107 & Unpublished data \\
\hline Tymianka & $S a$ & 2004-2011 & 116 & Unpublished data \\
\hline Wandów near Łuków & $\mathrm{Ta}$ & 1990-1991 & 257 & Unpublished data \\
\hline Warsaw Anin & $S a$ & 2014 & 105 & Lesiński et al. 2016c \\
\hline Warsaw Bielany & $S a$ & 1984-2017 & 753 & Lesiński \& Gryz 2012, unpublished data \\
\hline Warsaw Kabaty & $S a$ & 2005-2007 & 363 & Gryz et al. 2017 \\
\hline Warsaw Kawęczyn & $S a$ & 2010-2013 & 109 & Gryz et al. 2017 \\
\hline Warsaw Las Sobieskiego & $S a$ & 1993-2016 & 351 & Lesiński \& Stolarz 1999, unpublished data \\
\hline Warsaw Łazienki & Sa & 2004-2017 & 362 & Gryz et al. 2008, unpublished data \\
\hline Warsaw Młociny & $\mathrm{Sa}$ & 1982-2017 & 913 & Lesiński \& Gryz 2012, unpublished data \\
\hline Warsaw Natolin & Sa & 2004-2007 & 160 & Gryz et al. 2017 \\
\hline Warsaw Olszynka Grochowska & $\mathrm{Sa}$ & 2011-2014 & 237 & Gryz et al. 2017 \\
\hline Warsaw Skarpa Ursynowska & Sa & 2006-2012 & 125 & Gryz et al. 2017 \\
\hline Warsaw Tarchomin & $\mathrm{Sa}$ & 2008-2017 & 1,387 & Unpublished data \\
\hline Warsaw Zakole Wawerskie & Sa & 2011-2013 & 123 & Gryz et al. 2017 \\
\hline Węgrzynowo & $\mathrm{Ta}$ & 1992-2009 & 466 & Unpublished data \\
\hline Wieliszew & Ao & 2014-2016 & 852 & Unpublished data \\
\hline Wierzbica near Radom & $\mathrm{Ta}$ & 1993 & 497 & Unpublished data \\
\hline Wilczyska near Łuków & $\mathrm{Ta}$ & 1990-1993 & 767 & Unpublished data \\
\hline Wiskitki & $\mathrm{Ta}$ & 1988 & 136 & Unpublished data \\
\hline Wiśniew near Siedlce & $\mathrm{Ta}$ & 1990 & 253 & Unpublished data \\
\hline Wojcieszków near Łuków & $\mathrm{Ta}$ & 1991 & 728 & Unpublished data \\
\hline Wola Zadybska & $S a$ & 2009-2012 & 495 & Unpublished data \\
\hline Wola Żelechowska & Ao & 1988-1995 & 226 & Unpublished data \\
\hline Worów near Grójec & $\mathrm{Ta}$ & 1992 & 2,004 & Unpublished data \\
\hline Wólka Dworska, Vistula river & Sa & 2013 & 194 & Unpublished data \\
\hline Wólka Łasiecka & $\mathrm{Sa}$ & 2009-2016 & 411 & Lesiński et al. 2016a \\
\hline Wysoczyzna near Mława & $\mathrm{Ta}$ & 1991 & 325 & Unpublished data \\
\hline Zaborów Leśny (KNP) & $S a$ & 1980-1997 & 194 & Unpublished data \\
\hline Zacywilki & Ao & 2005-2009 & 1,290 & Gryz \& Krauze-Gryz 2015 \\
\hline Zacywilki & $S a$ & 2004-2007 & 177 & Gryz \& Krauze-Gryz 2016a \\
\hline Zakrzew near Radom & $\mathrm{Ta}$ & 1992 & 398 & Unpublished data \\
\hline Zalesie Górne I & Sa & 2010-2012 & 137 & Romanowski et al. 2014 \\
\hline Zalesie Górne II & $S a$ & 2010-2012 & 115 & Romanowski et al. 2014 \\
\hline Zalesie Górne III & Sa & 2010-2012 & 105 & Romanowski et al. 2014 \\
\hline Zalesie Górne IV & $S a$ & 2015 & 190 & Unpublished data \\
\hline Zasiadały near Garwolin & Ao & 1989-1991 & 219 & Unpublished data \\
\hline Zawady near Kampinos & $\mathrm{Ta}$ & 1993 & 463 & Unpublished data \\
\hline Zbójna Góra & Sa & 2015-2016 & 152 & Lesiński et al. 2016c \\
\hline Zembrów & $\mathrm{Ta}$ & 1990-2000 & 1,880 & Unpublished data \\
\hline Zielona near Żuromin & $\mathrm{Ta}$ & 1990 & 203 & Unpublished data \\
\hline Zielonka & $S a$ & 2002-2007 & 1,073 & Lesiński et al. 2016c \\
\hline Zielony Ług near Międzylesie & Sa & 2015-2016 & 146 & Lesiński et al. 2016c \\
\hline Zimna Woda near Rogów & Ao & 2004-2008 & 275 & Gryz \& Krauze-Gryz 2015 \\
\hline Zimna Woda near Rogów & $\mathrm{Sa}$ & 2004-2007 & 810 & Gryz et al. 2011b, unpublished data \\
\hline Złaków Kościelny & $\mathrm{Ta}$ & 2016 & 399 & Unpublished data \\
\hline Złaków Kościelny & Ao & 2016 & 1,233 & Unpublished data \\
\hline Złotokłos & Sa & 2006-2009 & 130 & Romanowski et al. 2016 \\
\hline Zwierzyniec & Sa & 2014-2016 & 600 & Unpublished data \\
\hline Zwola Poduchowna & Sa & 2015-2016 & 176 & Unpublished data \\
\hline Zwola Poduchowna & $\mathrm{Ta}$ & 1990 & 426 & Unpublished data \\
\hline Żabianka near Ryki & $\mathrm{Ta}$ & 1991 & 804 & Unpublished data \\
\hline Żelechów & $\mathrm{Ta}$ & 1994-2000 & 6,520 & Unpublished data \\
\hline Życzyn & $\mathrm{Ta}$ & 1993-1996 & 407 & Unpublished data \\
\hline
\end{tabular}

